\title{
Do Turkish Companies and German Companies in Germany Differ in Terms of Financial Performance?
}

\author{
Nurhan Aydin \\ Prof. Dr., Faculty of Economics and Administrative Sciences \\ Anadolu University, Turkey \\ E-mail: naydin@anadolu.edu.tr
}

Metin Coşkun

Assist. Prof. Dr., Faculty of Economics and Administrative Sciences

Anadolu University, Turkey

E-mail: metincoskun@anadolu.edu.tr

Arda Sürmeli

Research Assist. Dr., Faculty of Economics and Administrative Sciences

Anadolu University, Turkey

E-mail: asurmeli@anadolu.edu.tr

Gülşah Kulalı (Corresponding author)

Research Assist., Faculty of Economics and Administrative Sciences

Anadolu University, Yunusemre Campus, 26470 Eskişehir, Turkey

Tel: 90-222-335-0580 ext.3360 E-mail: gulsahy@anadolu.edu.tr

Received: December 13, 2011

doi:10.5539/ijbm.v7n5p40
Accepted: February 8, 2012

Published: March 1, 2012

This research was financially supported by TÜBİTAK, The Scientific and Technological Research Council of Turkey.

\begin{abstract}
Turkish immigrants have always been an important dynamic for the social and business life in Germany since October 1961, "Agreement for Sending the Turkish Workers to Germany". They have then started to become important players as entrepreneurs in the economy after 1990s. This study aims to analyze performance of Turkish and German companies in production and service industries operating in Germany by using financial analysis methodology, and it aims to compare the results. Using 2007 financial data, the empirical results show that Turkish firms in both industries take more liquidity risk than their German counterparts while they are using less leverage in order to finance their investments. Moreover, Turkish companies have less profitability than German companies with the effect of high cost of debt. Especially in service industry, Turkish firms have low level of return for a unit of risk and low level of output for a unit of input.
\end{abstract}

Keywords: Foreign companies, Immigrant entrepreneurship, Performance, Financial analysis

\section{Introduction}

Performance is a far-reaching concept related to levels of success for people or companies in reaching the desired results in a work or activity. Companies may detect problems via performance evaluation and take the 
necessary precautions hence increasing their efficiencies in their relevant activities. Companies have used various performance indicators at various times. Traditionally, performance was evaluated by the company partners and managers using financial measures. Nowadays, performance is not evaluated only from the viewpoints of company partners and managers but also from those of customers and similar stakeholders using nonfinancial indicators such as quality and customer satisfaction. In this study, companies are analyzed in terms of their financial performances.

It is not possible to use only one criterion when evaluating the financial performance of the companies. Financial performance may be evaluated by taking into account financial norms such as sales, cost, yield, efficiency, productivity, revenue, dividend, growth, share prices, total assets and return on equity. Traditionally, yield is considered as a basic performance indicator. Even though yield, efficiency and effectiveness are used synonymously in literature, they actually have different meanings. Yield and efficiency have similar meanings; however effectiveness and efficiency do not have the same meanings. In general, the efficiency of a company is defined as its success to produce the maximum output with the consumed inputs (Yolalan, 1993) whereas effectiveness determines the company's level of realizing its objectives. Effectiveness may not be obtained as efficiency increases; or the company may not be effective enough if the results obtained do not make the necessary contribution to the company goals no matter how efficient the work is. High performance may be reached when effectiveness and efficiency are realized together (Akal, 2003).

As is the case in the world, German economy is shaped by small and medium sized enterprises (SMEs). Even though SMEs generally face more problems in comparison with large enterprises, it is observed that they can deal with many more problems and rapidly grow in an ever increasing competition. The most important advantage of such companies is that they can adapt to the rapid changes in technology and consumer preferences much faster than large enterprises. Many German SMEs engage in international activities and attain considerable market share in niche markets. It is observed that in comparison with SMEs in other countries, German SMEs are more successful especially in export. German SMEs are generally managed by their owners, chase cost minimizing measures, strive to develop creative and novel products and follow newly developing markets and they make immense contributions to the employment, tax and trading volume of the German economy. However, the population in Germany is rapidly aging just like other European countries. Whereas $25 \%$ of the German population is aged over 60 , this ratio is $5 \%$ for Turkey. This in turn brings about the problem of the dwindling youth population which can lead the business world as new entrepreneurs. In order to overcome this important problem, politicians try to attract new investments to the country while developing policies to allure immigrants with high birth rate who are ready to take risks, young, dynamic and have high levels of entrepreneurship skills.

In the study carried out by Kadir Has University, Foreign Economic Relations Board (DEIK) and the Vale Columbia Center on Sustainable International Investment (VCC) (2009), foreign direct investments made by Turkish origined multinational companies were analyzed. This study is a branch of another more comprehensive study analyzing the development of multinational companies in developing countries. According to this study the outward foreign investments of Turkey decreased by $62 \%$ in the first 9 months of 2009 , in comparison to the the first 9 months of the previous year. It is stated that the decrease is largely due to the global financial crisis. The study was focused on the investments made by the largest 12 multinational Turkish origined companies. The investments of these 12 companies added up to 15.7 Billion Dollars in 2007. The foreign sales value of these companies was close to 11.9 Billion Dollars and the employment provided by these countries outside of Turkey was about 72334 people. Starting from 2006 up to 2007 assets, sales and employment increased by 32\%, 17\% and $37 \%$, respectively. $72 \%$ of the foreign subsidiaries were based in Europe.

Following the 2000 and 2001 economical crises, Turkish economy grasped the importance of direct foreign investments and thus established the Foreign Direct Investment Law in June, 2003. During the financial crisis of 2008, Turkish multinational companies were stronger and they benefited from the decreasing asset prices to establish strategic acquisitions.

Various studies have been carried out regarding the social, economical, cultural features of Turks living in Germany. However, no study was determined regarding the relevant company financial performances. The objective of this study is to carry out the financial analyses comparing the results for Turkish and German companies operating in the service and manufacturing industries. According to the Deutsche Bank 2007 data, there are total of 3036600 active companies of which 2997800 are micro and small, 30000 medium scale and 8800 large scale in Germany. According to the Foundation of Turkish Research Center, there are total of 70300 active companies with Turkish capital in Germany in 2007. It is estimated that about $92 \%$ of these companies are micro and small scaled. Within the scope of this research, total of 112 companies have been analyzed. 13 are micro scale with 6 Turkish and 7 German companies, 52 are small scale with 29 Turkish and 23 German 
companies, 27 are medium scale with 12 Turkish and 15 German companies and 20 are large scale with 9 Turkish and 11 German companies.

\section{Ethnic Entrepreneurship in Germany and Other OECD Countries}

Entrepreneurship is a sensitive structure that needs a suitable framework to develop. There are important differences among countries in terms of entrepreneurship environment and these differences have an impact on the economical success of companies. Economical status-related properties as well as risk apprehension of entrepreneurs and investors are important that they either strengthen or weaken entrepreneurship. In this respect, the development of new establishments such as risk capital and investment capital are important for countries. Shiller (2006) stated that countries do culturally differ in ways of supporting entrepreneurship. For instance some countries are more intellectual whereas others are more practicality inclined. Practicality inclined countries are more successful in business administration; however, in reality success in leading the new powers in economy passes through the balancing of intellectual and practical inclinations. The frequently studied topics in this field are cultural factors such as critical success and performance conditions of ethnic entrepreneurs, opportunities and barriers, structural factors such as social discrimination and unemployment, special values and skills, internal solidarity, commitment, flexibility, personal motivation, work ethics, contact with people of the same ethnic group and flexible finance arrangements and a mixture of these factors.

In ethnic group entrepreneurship literature, ethnic group connection and its relationship with the opportunity structure in the economy are used to explain the entrepreneurship output. According to cultural and demand oriented approaches, ethnic entrepreneurship is explained by class and ethnic resources. These resources may be real estate, capital or knowledge. Ethnic resources can also be cultural values and information chains, skills, leadership potential and solidarity. According to Valdez (2002) when these financial and human resources are combined, opportunities and social capital are formed. Demand oriented approach was later added to cultural approach and the integration of the ethnic group with the economy was handled. Entrepreneur company owners may be temporary immigrants who have nothing to lose, or immigrants with limited freedom of action who are discriminated by employers.

Researches indicate that there are differences among locals and immigrants in terms of establishing their own companies. Just like immigration, entrepreneurship is also related with taking risks and it can be accepted that immigrants have the proper attitude for establishing their own companies. Ethnic minorities are more inclined to entrepreneurship in comparison with the locals indicated to be related to the margination theory which states that new company establishments are triggered by hardships and negative experiences. According to this theory, establishment of a new company may not always be a planned action or a rational decision. For many people, new jobs start only with the breaking down of their past way of lives. The marginal social standings of people who cannot truly adapt to the social system such as ethnic or immigrant minorities force them to start their own jobs. For these people working in their own jobs is not only a tool to earn money, but also a means to be known and socially accepted.

Countries have differing approaches on support of governments to ethnic entrepreneurship. The main assumption is that ethnic entrepreneurs will benefit from the laws enacted in order to increase the number of entrepreneurs and entrepreneurship quality. These laws include restructuring of economy, ensuring a more transparent and service oriented bureaucracy, making tax regimes, supporting microcredit systems, ensuring that entrepreneurship training is part of the curriculum and enacting the supporting laws. One of the reasons why countries have differing viewpoints about this subject may be the different immigration histories. For instance, many north western European countries had mass immigration after the Second World War and these countries have developed their welfare arrangements earlier than other countries (Rath, 2010).

According to the neoclassical human capital theory, immigrants are classified as a group made up of individuals who like taking risks in order to increase their quality of life and maximize their incomes. They have the motivation for success and investment in human capital. Constant and Zimmerman (2006) defined immigrants as risk carriers who are dynamic and liable to starting their own business and creating new jobs. These people work very hard to accomplish their dreams thereby creating jobs and opportunities. On the other hand, unemployment and discrimination must be other factors that increase their motivation.

According to International Migration Outlook of OECD (2009), on average, immigrants display more entrepreneurship qualities in OECD countries in comparison to local people. $12.7 \%$ of working immigrants and $12 \%$ of working locals are dealing with entrepreneurship activities other than agriculture. Member countries have different immigrant entrepreneurship features in terms of the environment, various limitations that immigrants may face, features of immigration tendencies and the sectoral distribution of immigrant workers. 
One of the most important signifiers for being involved in entrepreneurship activities is stated to be the personal history and experience of the individual. In general, entrepreneurs are middle aged and qualified males. Of the entrepreneurs in OECD countries, one fourth is over the age of 35 and those of foreign country origin are younger than the local entrepreneurs. Two thirds of the immigrant entrepreneurs have been living at the host country for over 10 years. Of the salaried employee immigrants $50 \%$ fall in this category. At a certain age immigrants are faced with lower social capital, limited financing tools and difficulties in finding funds. It is observed that these limitations decrease as the immigrant's duration of stay at the host country increases.

In all OECD countries the ratio of female entrepreneurs to that of the male entrepreneurs is lower for both those immigrants who were foreign-born and those who were native-born at that country. A very small fraction of all native-born and foreign-born female immigrants are involved in entrepreneurship activities in all OECD countries. The ratio of female entrepreneurs in OECD countries is 30\%. In many OECD countries, the ratio of the immigrant female entrepreneurs to the total female entrepreneurs is higher in comparison to the ratio of the local female entrepreneurs to the total female entrepreneurs. In Ireland, England, Sweden and Slovakia this difference is at least $10 \%$. On the other hand, in countries such as Austria, Switzerland and Portugal the ratio of local entrepreneurs to the total number of female entrepreneurs is higher.

Thirteen percent of the total population is composed of foreign-born individuals in Germany which place them to the second rank after USA among OECD countries in terms of immigration (http://www.oecd.org/). Therefore Germany's immigrant entrepreneurship policy is becoming more emphasized than past in recent years. Kontos (2007) stated that the Independent Immigration Commission considers self-employed immigrants with a better income structure in comparison with salaried employees as a successful result of social integration. Immigrant entrepreneurs who also present new opportunities for younger population are perceived as a positive factor for the development of economy in general and the labor market. The Commission clearly states that immigrant entrepreneurs should be supported. This is the case for immigrants from non EU countries who are less in number.

Immigrant entrepreneurship in Germany is recognized within a corporate framework including chambers of commerce, banks, labor bureaus and unions. Having a corporate environment is an advantage for the preparation of a policy to support entrepreneurs about topics such as credits or consultancy. Kontos (2007) stated that in practice, immigrant entrepreneurs do not sufficiently use these opportunities. In the officials of associations' opinion, immigrant entrepreneurs do not need corporate consultancy. They receive the support they need from the ethnic community and the ethnic economy. In reality, immigrant entrepreneurs obtain the capital required to start a business by loans from their family members and friends; very few immigrants use bank credits.

For the case of Turkish immigrants, it has been clarified by the concerning authorities that the immigration from Turkey to Germany is not only a visiting immigrant worker movement. Today, Turkish immigrants make up more than $30 \%$ of the population in some German cities. The liberalization movements in Turkey following the 1980 s along with the facts that Turkish entrepreneurs went abroad and that foreign entrepreneurs were encouraged to be active in Turkey had positive effects on Turkish entrepreneurs in Germany. Especially in the 1990s, German based companies have also started to be active in Turkey along with Turkish based companies in Germany. Commercial joint ventures between Turks and Germans continue to increase as well.

Entrepreneurship which is a common characteristic of Turkish people not only contributes to the economical development but also eases the integration of Turks with commercial relations and helps to increase the mutual understanding between the Turkish and German societies. The increases in the number of Turkish people who start their own companies provide remarkable employment opportunities to both sides.

\section{Literature Review}

It is observed in literature that companies operating in different foreign countries and the activities and performances of local and foreign companies in a home country have been studied frequently. Besides country difference, management understanding and cultural differences are also seen as important factors that affect the performance of companies. It is seen that many studies have compared the corporate management principles and systems of American, Japanese and German companies. Contrary to the American system, the German and Japanese systems are more relationship focused and the managers are continuously monitored by banks, large corporate shareholders and other relevant parties. In this case it can be stated that the company targets and performances are affected from this difference. This section includes local and foreign capital companies active in Germany and the studies on the performances of these companies.

In a study carried out by Kaplan (1994), it was determined that the turnover rate has a statistically significant relationship with stock return and gain/loss; however it was put forth that it has no statistically significant 
relationship with sales increase or income growth in Germany. In another study carried out by De Jong and Woutre (1997), Germanic companies were evaluated as those that do not give autonomous decisions and that they give decisions in accordance with the power distribution and the consensus with interest groups.

Miller, Jaspersen and Karmokolakis (1997) have determined the problems in joint ventures between local and foreign companies in developing countries to be valuation problems, transparency, conflict resolution, distribution of management responsibilities, transfer of proprietary rights, dividend policy, marketing and operational topics. On the other hand, Gedajlovic and Shapiro (1998) stated that the corporate management system features in Germany is low ownership distribution, the fact that company owners are banks or corporations in general, that the executive board members are company owners and employees, share holders have a great power over the company and that the basic financing option is loan.

In a relevant study carried out in Germany by Köke (1999), it was determined that German companies have a dense ownership structure. Whereas Januszewski, Köke and Winter (2001) have concluded that competition and strict control complement each other in the German manufacturing industry.

In the studies of Jungnickel and Keller (2003), it was determined that foreign owned companies active in Germany had productivity advantages over local companies but that they cannot gain this advantage when compared with multinational companies active in Germany with headquarters in Germany. It was also observed that the demand for qualified manpower of foreign owned companies is higher than that of the German companies. Lehman, Warning and Weigand (2004) concluded that the differences in the profitability of companies can be explained by the activities of these companies. It is seen that this result is valid even after the sectoral effects and unobserved systematic effects are controlled. The differences between the company owner groups were not determined to be statistically significant. The asset profitability of companies determined to be active were also observed to be high. According to the studies of Franks, Mayer and Wagner (2005), as German companies continued to issue shares, the shares of family members decreased in time whereas the shares of banks have increased. It has also been observed that there is a drift from bank credits to the issue of shares in the finance structure of German companies.

Seifert, Gönenç and Wright (2005) have concluded that the differences in the ownership structure gained importance due to the differences between local laws and management styles. They have also concluded that the control variables have statistically significant positive and negative effects on performance.

Mueller and Spitz (2006) have put forth that there is a positive relationship for up to about $40 \%$ of the management share between management share and performance and that as management share is distributed among less managers the performance increases as a result of their study.In another study, Arnold and Hussinger (2006) have listed companies in terms of total factor efficiency according to a non-parametric test and have concluded that exporting German companies are more efficient only in comparison to companies that are active in the local market and that German multinational companies are more efficient than both exporting and local companies.

Venohr and Meyer (2007) stated that the secret behind successful companies is related to common properties such as the fact that they are world leaders in their own markets, that they are focused on niche markets and have focused strategies, that they are carrying out their product expertise in the global market via their own branches, that they are value oriented instead of price, that they are innovative in terms of product and process, that they are focused on their strong aspects, that their value chains are not wide but narrow and deep, that they have a very strong corporate culture and that their leaders are very strong and experienced.

In his study Metzger (2007) determined that the experience of the entrepreneur is an important factor in the finance problems of new establishments. He also stated that the effect of this factor depends on the type of experience - for instance on how this experience was obtained. If the experience of the entrepreneur was an unsuccessful one - for instance if his/her latest establishment went bankrupt - it has been determined that his/her financing demand is lower. The reason for this has been specified to be the low credibility of the entrepreneur or the decrease in the tendency of the entrepreneur to take risks. It has also been determined that the experience of the entrepreneur also affects his/her selection of financing resources. Lastly, it has been stated that the German public is more scared than making a mistake in comparison with the public of other countries and that the German public may be more abstaining to start a new establishment due to the financial risks involved.

Temouri, Driffield and Higon (2008) have determined that non-internationalized German companies are less efficient in comparison with foreign companies and that there is no difference in terms of efficiency between international German companies and foreign companies. Another important conclusion of this study is the fact that there is an important relationship between the location of the companies and efficiency and that the 
companies in the east are less efficient than those in the west. The real accentuated conclusion in this study is that in terms of the difference in efficiencies, it is more important whether the company is national or international than whether the company is local or foreign. It is also stated that there is a significant variance in terms of efficiency difference between eastern and western regions of Germany. Efficiency difference in the eastern region is greater than that of the western region.

Arndt and Mattes (2008) have compared the performances of the foreign direct investments in Germany with the performances of the local companies and has obtained that foreign multinational companies are more productive than local multinational companies even though they are smaller; however there is no significant difference in terms of their price structures.

Results of another study -Schulte and Bettina (2008)- have been obtained via a semi-structured qualitative interview. It has been determined that second generation Turkish entrepreneurs move out of food-drink and small scale services to lean towards ventures in information and communication technologies. It is seen that this group which wants to define itself as Turkish-origin instead of "Almancı" has preferred virtual networks. Many of the entrepreneurs of Turkish origin in Germany have stated that they want to start a business in Turkey as well. In the study, the properties of this group which is the largest minority in Germany with a diasporic identity have been explained.

In a study carried out in Germany by Fryges and Wagner (2008) on the manufacturing industry, by using the variable of profitability new dimensions have been determined in the relationship between export and company performance. It has been determined that the profitability of manufacturing establishments that export their products is higher than that of those that do not export their products. It has been determined that this effect is the causality relationship not from profitability to export but vice versa. This is different for companies that export more than $90 \%$ of their sales. This has been related to the wage bills and other costs related with export.

Krivogorsky and Grudnitski (2009) have determined a strong positive relationship between financial performances of companies with banks or family/individuals as majority shareholders. A strong negative relationship has been determined with financial performance in companies with other companies as their majority shareholders. Countrywise differences have also been determined. On the other side, Fronningen and Wijst (2009) have examined the relationship between the ownership structures of the largest 70 establishments in Germany with their performance and they concluded that ownership structures are determined in terms of company properties and company environment; there is a weak relationship between ownership structure and company performance, and even though company ownership structure has an effect on performance, company performance has no effect on ownership structure.

In their studies, Block, Sandner and Spiegel (2009) have aimed to evaluate the attitudes of different entrepreneur groups in Germany towards risk. As a result, it has been determined that opportunity entrepreneurs have a greater tendency to take risks in comparison to need entrepreneurs and that entrepreneurs who are motivated by creativity have a greater risk tolerance in comparison to others.

\section{Data and Methodology}

\subsection{Data}

Within the scope of this research, 112 companies with German capital and Turkish capital or are Turkish origined and active in Germany have been selected according to the availability of financial and non-financial data. Among 112, 13 are micro scaled (6 Turkish and 7 German), 52 are small scaled (29 Turkish and 23 German), 27 are medium scaled (12 Turkish and 15 German) and 20 are large scaled (9 Turkish and 11 German) were included. European Union definitions and criterias of scales were used while assigning the scales. First, the Turkish origined companies are determined. Then, German companies that are similar to Turkish origined companies in terms of sector, geographical location and assets size have been determined. Turkish origined companies were designated in the light of information obtained from the databases of the Association of Turkish German Businessmen and Academics (TAIAD), European Association of Turkish Businessmen and Industrialists (ATIAD), Union of Turkish - German Businessmen (TDU) and the Association of Turkish Businessmen in Europe (BTEU). After this stage, the designated companies were searched in the database Dafne. In Dafne, 56 Turkish companies with complete financial and non-financial data were determined. Then, 56 German counterparts included also from the Dafne database.

The service and manufacturing industries distribution of companies according to geographical regions of Germany have been given in Table 1. The total assets of Turkish origined companies are very close to their German counterparts and their sectoral and geographical distribution is nearly identical. This similarity is also 
valid on the basis of companies one to one in two groups.

The financial and non-financial data about companies were obtained from the Dafne database of Bureau van Dijk Electronic Publishing. Dafne is a database containing the comparable financial and non-financial data of about 950000 private and public companies active in Germany. As a result of studies carried out using the database, 2007 determined as the year which contains the maximum available data, at the same time which can represent a normal period without any economic or financial crisis.

\subsection{Methodology}

Ratio analysis, which is a frequently used method for the evaluation of financial status and the activity results of firms, is used in this study in order to carry out the financial analysis. The most widely preferred methods in financial analysis can be listed as; ratio analysis, vertical analysis and horizontal analysis. In this study, ratio analysis is preferred since the results of one year (2007) are evaluated for all companies and that the company and industry groups are also evaluated comparatively. The generally used financial ratios can be classified as;

- Ratios used for the liquidity status analysis of a firm,

- Ratios about the financial structure of a firm,

- Efficiency ratios related with the usage of assets,

- Ratios used to measure the profitability,

- Ratios used to measure the market performance of a firm.

It was aimed to select the ratios so that they are linked causally to the production process and to represent this process as accurately as possible. "Current ratio" (current assets/short term debt) was used to analyze the liquidity status of the companies, "Total Debt/Total Assets" and "Short Term Debt/Total Debt" ratio was used analyze the financial structure, "Net Profit/Shareholder's Equity", "Net Profit/Total Assets", "Net Profit/Net Sales", "Earning Before Interest and Tax (EBIT)/Net Sales" and "Earning Before Intrest, Tax and Depreciation (EBITDA)/Net Sales" ratios were used to analyze the profitability of the companies. The efficiency ratios related to the usage of assets and to the market performance were not included since the relevant financial data could not be obtained. In order to ensure the obtainability, comparability and reliability of the data and frigid attitudes of companies in sharing information regarding their operations and results, it was decided to use standard financial tables in the form of secondary data in the analysis. Therefore, the standard financial tables of selected 112 companies for 2007 were obtained from the Dafne Database.

\section{Analysis Results}

The average values of the financial ratios for the 44 Turkish and 43 German companies active in the service industry for a total of 87 companies along with the financial ratios for the 12 Turkish and 13 German companies for a total of 25 companies have been given in Table 2 and Table 3, respectively. The first columns of these two tables contain the ratios for only the Turkish companies, the second columns contain the ratios for only the German companies, the third columns contain the ratios for all the Turkish and German companies and the fourth columns contain the ratios of the one thousand largest (first thousand) companies in the relevant sectors according to 2007 data.

Current ratio was used to determine the solvency for short term debts and to determine whether the net working capital is sufficient or not. It was used as an index displaying the current financial power of a business. As a general rule, it is accepted efficient for companies to have a current ratio of 1.50 for companies active in the service industry and a current ratio of 2.00 for companies active in the manufacturing industry. When the current ratios of the Turkish and German companies in the service sector are examined, it can be stated that even though the current ratio of Turkish companies (1.46), it is below the accepted value of 1.50 whereas the current ratio of German companies (1.62) is above this value. The current ratio of the total of 87 (Turkish and German) companies active in the service sector is 1.54 which could be evaluated as required value. In this case, it is observed that Turkish companies have fewer current assets than the required amount whereas German companies have greater current assets than the required amount. When the standard deviations are examined, it can be stated that the deviation in the current ratio of German companies is twice the Turkish companies'.

For the manufacturing industry, it can be stated that the current ratio of Turkish companies (1.49) is about $25 \%$ smaller than the accepted value of 2.00, whereas this value for German companies (2.25) is greater. The current ratio of the total 25 (Turkish and German) companies active in the manufacturing industry is 1.93. In parallel to the evaluations made for the service industry, it can be stated that Turkish companies operate with fewer current assets than the required amount and that German companies operate with more current assets than the required 
amoount.

Debt (leverage) ratio shows what percentage of the assets of a company is financed by debt. A high value of the leverage ratio means that the business is financed in a risky manner and that the probability for the company to fail in meeting the interest obligations is high. The leverage ratios for the Turkish and German companies active in the service sector are calculated respectively as $85 \%$ and $91 \%$, whereas the leverage ratios for the Turkish and German companies active in the manufacturing industry are calculated respectively as $77 \%$ and $71 \%$. In the service sector, Turkish companies use fewer loans than German companies, whereas in the manufacturing industry they use more loans. When the leverage ratio for the first thousand companies is compared with the leverage ratio for the Turkish and German companies, it can be stated that Turkish companies use $20 \%$ more debt in comparison with the first thousand companies whereas the same ratio for German companies is $30 \%$ more. This means that the German companies are in a more risky position in comparison with the Turkish.

Another important risk indicator is the share of short term debt in the total debt. Since the increase of the short term debt will require renewing of short term loans frequently, it can create a debt payment problem for a company. When the debt distributions of German and Turkish companies are examined, it can be recognized that 56 percent of total debts of Turkish companies in the service sector are short-term, the same ratio for German companies is 65 percent. For the manufacturing industry, it can be observed that 51 percent of the total debts of Turkish companies is short-term whereas the same ratio for German companies is 60 percent. The percentage of the short-term debt of the first thousand companies is $49 \%$ for the service industry, and about $48 \%$ for the manufacturing industry. The fact that the short-term debt ratio for the manufacturing sector is smaller than the service sector may be seen as a natural result since manufacturing companies generally prefer long term loans instead of short term loans for the financing of their fixed assets.

The liquidity and financial structure ratios could be summarized as follows; Turkish companies are at a more risky position in terms of liquidity whereas German companies are at a more risky position in terms of leverage.

When the profitability of the Turkish and German companies are compared using "Net Profit/Net Sales", "EBIT/Net Sales" and "EBITDA/Net sales", it can be observed that German companies have an absolute superiority over Turkish companies especially in the service sector. The profitability value calculated for German companies in the service sector using "Net Profit/Net Sales" is about 6 times greater than that calculated for the Turkish companies. The profitability value calculated for German companies using "EBIT/Net Sales" is about 3 times greater than the profitability calculated for Turkish companies and the profitability value calculated for German companies using "EBITDA/Net Sales" is about 2 times greater than the profitability value calculated for Turkish companies. When the Turkish and German companies are compared with the first thousand companies in terms of the 3 aforementioned profitability ratios, German companies show similarities with the first thousand companies whereas Turkish companies are way behind the first thousand companies. In addition, both Turkish and German companies are behind the first thousand companies in the manufacturing industry.

The financial performance of Turkish companies over equity capital both in the service and the manufacturing industry is much lower than that of German companies. The profitability over shareholder's equity of German companies is 3.5 times and 2.5 times greater than that of the Turkish companies in the service sector and in the manufacturing sector, respectively. For the profitability over assets, Turkish companies have a superiority of about $27 \%$ to German companies in the service sector, whereas in the manufacturing sector German companies have a superiority of about $27 \%$ to Turkish companies. However, when Turkish and German companies are compared with the first thousand companies, their profitability over assets is half the values of the first thousand companies.

The relationships between risk and yield positions of Turkish and German companies are given in Figure 1. If a generalization should be made for the examined profitability ratios, it can be stated that the profitability of German companies are greater than those of the Turkish companies in both sectors. If this result is examined along with the liquidity and financial structure ratio evaluations, it is observed that the profitability of Turkish companies which take high risks in terms of liquidity are lower than the German companies, whereas the profitability of German companies that take risks in terms of financial structure is higher than the profitability of Turkish companies. Liquidity ratio along with the leverage ratio from the financial structure ratios group are transformed into one risk value, and the "Net Profit/Shareholder's Equity" and "Net Profit/Net Sales" ratios are transformed into a single yield value using the functions below: 


$$
\begin{aligned}
& \text { Risk }=0.5(\text { CurrentRatio })^{-1}+0.5(\text { LeverageRatio }) \\
& \text { Yield }=0.5(\text { NetIncome } / \text { Equity })+0.5(\text { NetIncome } / \text { NetSales })
\end{aligned}
$$

The Figure 1 is divided into four sections at the average risk and average yield point of $6.75 \%$ and $14.52 \%$ point. The $1^{\text {st }}$ section represents high risk high yield, the $2^{\text {nd }}$ section represents low risk high yield, the $3^{\text {rd }}$ section represents low risk, low yield and the $4^{\text {th }}$ section represents high risk and low yield. Companies in the $1^{\text {st }}$ and $3^{\text {rd }}$ sections are reasonable financially, and they reflect the risk preference of the companies. In other words, companies accept low yield for low risk or high yield for high risk. Whereas German companies in the service sector accept high yield for high risk, German companies in the manufacturing sector accept low yield for low risk. Turkish companies in both sectors are in the $4^{\text {th }}$ section. They gain low yield under high risks and this is contradictory to the basic finance law of risk and yield relationship. When the 56 German companies participating in the study are compared with the first thousand companies in their sectors in terms of risk and yield relationship, they are at a very disadvantageous point.

\section{Evaluation}

Turkish immigrants comprise the largest immigrant population of Germany which hosts the largest immigrant population in Europe. The contribution to the German economy of Turkish immigrants who are celebrating their $50^{\text {th }}$ anniversary this year in Germany both as consumers and investors cannot be ignored. Many of those who went to Germany with the aim of eventually returning home are now permanent Turkish-German citizens and whereas they used to work as laborers most have established their own companies forming the most dynamic group among other immigrants in Germany. Even though most of the 70000 companies established by Turkish entrepreneurs are at a micro-level, many have succeeded to operate not only in Germany but in other European countries as well. Turkish companies also have institutions or representative offices established in Germany.

The interest of companies established by entrepreneurs coming from Turkey with different ethical values and different features to attain financial success in Germany has led researchers to this area of study. It is thought that this study will benefit both the companies and the potential entrepreneurs in Germany, which is financially one of the most developed economics in Europe.

The results of this study can be summarized as below:

When the liquidity power of companies active in the service and manufacturing sectors are compared, it is possible to state that the liquidity power of German companies in both sectors is higher than the liquidity power of Turkish companies; hence Turkish companies pose a greater risk in terms of repaying their short term debts. The difference is higher for manufacturing sector.

When companies are evaluated in terms of the financing of assets, it is observed that Turkish companies in service sector use less leverage than the German companies whereas they use more leverage in manufacturing sector. Turkish companies use about $20 \%$ more debt and German companies use about $30 \%$ more debt than first thousand companies in Germany. In other words, Turkish companies use more shareholders' equity than credits for the financing of assets. Thus, Turkish companies can increase their yield by using low credit interests.

If the liquidity and financial structure are examined together, they imply that the Turkish companies are more risky in terms of liquidity whereas German companies are more risky in terms of leverage. Turkish companies should focus on the net working capital. They should try to balance the current assets with short term debt.

When companies are considered in terms of profitability on sales and profitability on equity, it is seen that the profitability of German companies are greater than those of the Turkish companies in both sectors. The difference is higher in service sector for profitability on sales. On the other hand, Turkish companies in service industry are about $27 \%$ superior in terms of profitability on assets and they are about $27 \%$ inferior in manufacturing industry.

The fact that the difference between "EBIT/Net Sales" ratio and "Net Profit / Net Sales" ratio is greater for Turkish companies in comparison to German companies which specifies that the cost of borrowing for Turkish companies is greater. Turkish companies also should focus on lowering the cost of borrowing. The experience, reputation and the quality of income are important for credibility.

Risk and yield together analyzed, German service companies achieve high level of yield for high level of risk while German manufacturing companies accept low level of yield for low level of risk. Turkish companies in both sectors achieve low level of yield for high level of risk. The amount of output they obtain in relation to the input is quite low. Turkish companies should basically increase their income in order to maintain the balance 
between risk and yield. This can be achieved by serving not only the ethnic market but the whole market. In case these companies increase their income, it can be expected that their profitability will increase and thus the balance between risk and yield will be established.

\section{References}

Akal, Z. (2003). Performans Kavramları andPerformans Yönetimi. Başbakanlık Yüksek Denetleme Kurulu, National Center of Productivity Seminar Note, Ankara.

Arndt, Christian and Ansalm Mattes. (2008). The Impact of Inward FDI and Foreign Ownership on the Performance of German Multinational Firms, German Science Foundation Project, BU 1256/6-1, SFB-TR 15.

Arnold, Jens Matthias and Katrin Hussinger. (2006). Exports versus FDI in German Manufacturing: Firm Performance and Participation in International Markets. Deutsche Bundesbank Discussion Paper Series 1: Economic Studies No: 04.

Block, J., P. Sandner and F. Spiegel. (2009). Do Risk Attitudes Differ within the Group of Entrepreneurs?. Munich Personal RePEc Archive Paper No. 17587.

Constant, A., and K.F. Zimmermann. (2006). The Making of Entrepreneurs in Germany: Are Native Men and Immigrants Alike?. Small Business Economics, 26, pp.279-300. http://dx.doi.org/10.1007/s11187-005-3004-6

De Jong, \& Henk Woutre. (1997). The Governence Structure and Performance of Large European Corporations. The Journal of Management and Governance, 1, pp.5-27. http://dx.doi.org/10.1023/A:1009931211940

Deutsche Bank. (2007). More Growth for Germany. Deutsche Bank Research, July 6.

Franks, J., C. Mayer and H.F. Wagner. (2005). The Origins of the German Corporation-Finance, Ownership and Control. European Finance Assosiation Meeting, Moscow.

Frges, Helmut and Joachim Wagner. (2008). Exports and Profitability- First Evidence for German Manufacturing Firms. Centre for European Economic Research (ZEW) Discussion Paper No. 08- 085.

Fronningen, L.A., and N. van der Wijst. (2009). Ownership Structure and Performance of The Largest German Companies. [Online] Available: http://ssrn.com/abstract=1341615

Gedajlovic, E.R., and D.M. Shapiro. (1998). Management and Ownership Effects: Evidence from Five Countries. Strategic Management Journal, pol.533-553. http://dx.doi.org/10.1002/(SICI)1097-0266(199806)19:6<533::AID-SMJ957>3.0.CO;2-\#

Januszewski, S.I., J. Köke and J.K Winter. (2001). Product Market Competition, Corporate Governance and Firm Performance: An Empirical Analysis for Germany, Sonderfor schungsbereich 504, University of Mannheim.

Jungnickel, Rolf and Dietmar Keller. (2003). Foreign Owned Firms in the German Labour Market. Hamburgisches Welt-Wirtschafts-Archiv Discussion Paper 233.

Kadir Has University, Vale Columbia Center on Sustainable International Investment and Foreign Economic Relations Board. (2009). Survey Provides the First Ever Ranking of Turkish Multinationals Investing Abroad, İstanbul and New York.

Kaplan, Steven N. (1994). Top Executives, Turnover, and Firm Performance in Germany. Journal of Law, Economics \& Organization, Vol.10, No.1, pp.142- 1459. http://dx.doi.org/10.1093/jleo/10.1.142

Kloosterman, Robert and Jan Rath. (2003). Immigrant Entrepreneurs: Venturing Abroad in the Age of Globalization. Berg Publishing, New York.

Köke, F. Jens. (1999). New Evidence on Ownership Structures in Germany. Centre for European Economic Research (ZEW) Discussion Paper No. 99-60.

Kontos, Maria. (2007). Immigrant Entrepreneurs in Germany. Handbook of Research on Ethnic Minority Entrepreneurship, Leo-Paul Dana (Editor). Edward Elgar Publishing, Inc. pp.445-462, UK.

Krivogorsky, Victoria and Gary Grudnitsky. (2011). Dominant Owners and Financial Performance of Continental European Firms. [Online] Available: http://ssrn.com/abstract=1086469

Lehmann, Eric, Susanne Warning and Jürgen Weigand. (2004). Governence Structures, Multidimensional Efficiency and Firm Performance. Journal of Management and Governance, 8, pp.279- 304. http://dx.doi.org/10.1007/s10997-004-1116-z

Metzger, Georg. (2007). On the Role of Entrepreneurial Experience for Start- up Financing: An Emprical 
Investigation for Germany. Centre for European Economic Research, Discussion Paper No. 07- 047.

Miller, R., J. Glen, F. Jaspersen and Y. Karmokolias. (1997). International Joint Ventures in Developing Countries. Finance \& Development, March, pp.26-29.

Mueller, E., and A. Spitz-Oener. (2006). Managerial Ownership and Company Performance in German Small and Medium Sized Private Enterprises. German Economic Review, 7(2), pp.233-247. http://dx.doi.org/10.1111/j.1468-0475.2006.00154.x

OECD. (2009). Migration Outlook. OECD Publishing.

OECD. (2010). Open for Business: Migrant Entrepreneurship in OECD Countries. OECD Publishing.

Rath, Jan. (2010). Ethnic entrepreneurship Concept paper, Institute for Migration and Ethnic Studies (IMES) at the University of Amsterdam, Research project: Labour market mobility and access to social rights for migrants, European Foundation for the Improvement of Living and Working Conditions.

Schulte, Bettina. (2008). Second Generation Entrepreneurs of Turkish Origin in Germany: Diasporic Identity and Business Engagement, Centre on Migration, Citizenship and Development Working Papers No.56.

Seifert, Bruce, Halit Gönenç and Jim Wright. (2005). The International Evidence on Performance and Equity Ownership by Insiders, Blockholders, and Institutions. Journal of Multinational Financial Management, 15, pp.171- 191. http://dx.doi.org/10.1016/j.mulfin.2004.08.003

Shiller, Robert J. (2006). Innovations to Foster Risk-Taking and Entrepreneurship. Joint Conference of CESifo and the Center on Capitalism and Society: Perspectives on the Performance of the Continent's Economies, Venice Internetional University, San Servolo.

Temouri, Y., N.L. Driffield and D.A. Higon. (2008). Analysis of Productivity Differences among Foreign and Domestic Firms: Evidence from Germany. Kiel Institute for the World Economy, pp.32-45.

Valdez, Zulema. (2002). Ethnic Entrepreneurship: Ethnicity and the Economy in Enterprise, The Center for Comparative Immigration Studies, Working Paper 63.

Venohr, Bernd and Klaus E.Meyer. (2007). The German Miracle Keeps Running: How Germany's Hidden Champions Stay Ahead in the Global Economy, Berlin School of Economics, Business \& Management Working Paper No:30.

Yolalan, Reha. (1993). Isşletmeler Arası Göreli Etkinlik Ölçümü. MPM Yayınları, No: 483, Ankara, pp.7-40. [Online] Available: http://www.oecd.org (12.05.2011)

Table 1. The Ownership, Sectoral and Geographical Distributions of Companies

\begin{tabular}{|l|ll|ll|}
\hline \multirow{2}{*}{ Geographical Region } & \multicolumn{2}{|l|}{ Turkish Companies } & \multicolumn{2}{l|}{ German Companies } \\
\cline { 2 - 5 } & $\begin{array}{l}\text { Service } \\
\text { (Units) }\end{array}$ & $\begin{array}{l}\text { Industry } \\
\text { (Units) }\end{array}$ & $\begin{array}{l}\text { Service } \\
\text { (Units) }\end{array}$ & $\begin{array}{l}\text { Industry } \\
\text { (Units) }\end{array}$ \\
\hline Baden-Württemberg & 4 & & 4 & \\
\hline Bayern & 2 & 2 & & 4 \\
\hline Berlin & 5 & 2 & 5 & 1 \\
\hline Brandenburg & 2 & & 2 & \\
\hline Hamburg & 1 & 1 & \\
\hline Hessen & 5 & & 5 & 1 \\
\hline Niedersachsen & 3 & 2 & 5 & 1 \\
\hline Nordrhein-Westfalen & 16 & 3 & 14 & 3 \\
\hline Rheinland-Pfalz & 1 & & 1 & 1 \\
\hline Saarland & 3 & & 2 & 1 \\
\hline Sachsen & & 1 & 1 & \\
\hline Sachsen-Anhalt & 2 & & 2 & \\
\hline Thüringen & & 2 & 1 & 1 \\
\hline Total & $\mathbf{4 4}$ & $\mathbf{1 2}$ & $\mathbf{4 3}$ & $\mathbf{1 3}$ \\
\hline
\end{tabular}


Table 2. The Average Values of the Ratios for Establishments Active in the Service Industry

\begin{tabular}{|c|c|c|c|c|c|c|c|c|}
\hline & \multicolumn{8}{|c|}{ Companies Active in the Service Industry } \\
\hline & \multicolumn{2}{|c|}{ Turkish (total 44) } & \multicolumn{2}{|c|}{ German (total 43) } & \multicolumn{2}{|c|}{$\begin{array}{l}\text { General (total } \\
44+43)\end{array}$} & \multicolumn{2}{|c|}{ First 1000} \\
\hline & Average & $\begin{array}{l}\text { Std. } \\
\text { deviation }\end{array}$ & Average & $\begin{array}{l}\text { Std. } \\
\text { deviation }\end{array}$ & Average & $\begin{array}{l}\text { Std. } \\
\text { deviation }\end{array}$ & Average & $\begin{array}{l}\text { Std. } \\
\text { deviation }\end{array}$ \\
\hline $\begin{array}{l}\text { Current } \\
\text { Ratio }\end{array}$ & 1.46 & 0.72 & 1.62 & 1.58 & 1.54 & 1.23 & 1.96 & 1.34 \\
\hline $\begin{array}{l}\text { Total Debt / } \\
\text { Total Assets }\end{array}$ & $84.89 \%$ & $24.80 \%$ & $91.42 \%$ & $38.61 \%$ & $88.12 \%$ & $32.35 \%$ & $70.43 \%$ & $21.16 \%$ \\
\hline $\begin{array}{l}\text { Short Term } \\
\text { Debt / Total } \\
\text { Debt }\end{array}$ & $55.88 \%$ & $36.15 \%$ & $64.96 \%$ & $35.21 \%$ & $60.37 \%$ & $35.77 \%$ & $49.39 \%$ & $27.51 \%$ \\
\hline $\begin{array}{l}\text { Net Profit / } \\
\text { Shareholder' } \\
\text { s equity }\end{array}$ & $7.95 \%$ & $120.94 \%$ & $27.57 \%$ & $52.92 \%$ & $17.64 \%$ & $93.69 \%$ & $53.20 \%$ & $202.83 \%$ \\
\hline $\begin{array}{l}\text { Net Profit / } \\
\text { Total Assets }\end{array}$ & $5.19 \%$ & $14.75 \%$ & $4.10 \%$ & $9.70 \%$ & $4.65 \%$ & $12.45 \%$ & $8.58 \%$ & $16.69 \%$ \\
\hline $\begin{array}{l}\text { Net Profit / } \\
\text { Net Sales }\end{array}$ & $0.41 \%$ & $9.15 \%$ & $2.60 \%$ & $5.97 \%$ & $1.49 \%$ & $7.77 \%$ & $5.29 \%$ & $9.59 \%$ \\
\hline $\begin{array}{l}\text { EBIT / Net } \\
\text { Sales }\end{array}$ & $2.43 \%$ & $7.81 \%$ & $6.67 \%$ & $20.64 \%$ & $4.52 \%$ & $15.59 \%$ & $5.82 \%$ & $9.13 \%$ \\
\hline $\begin{array}{l}\text { EBITDA / } \\
\text { Net Sales }\end{array}$ & $4.69 \%$ & $8.22 \%$ & $9.62 \%$ & $31.91 \%$ & $7.13 \%$ & $23.18 \%$ & $9.56 \%$ & $12.04 \%$ \\
\hline
\end{tabular}

Table 3. The Average Values of the Ratios for Establishments Active in the Manufacturing Industry

\begin{tabular}{|c|c|c|c|c|c|c|c|c|}
\hline & \multicolumn{8}{|c|}{ Companies Active in the Manufacturing Industry } \\
\hline & \multicolumn{2}{|c|}{ Turkish (total 12) } & \multicolumn{2}{|c|}{ German (total 13) } & \multicolumn{2}{|c|}{$\begin{array}{l}\text { General (total } \\
12+13)\end{array}$} & \multicolumn{2}{|c|}{ First 1000} \\
\hline & Average & $\begin{array}{l}\text { Std. } \\
\text { deviation }\end{array}$ & Average & $\begin{array}{l}\text { Std. } \\
\text { deviation }\end{array}$ & Average & $\begin{array}{l}\text { Std. } \\
\text { deviation }\end{array}$ & Average & $\begin{array}{l}\text { Std. } \\
\text { deviation }\end{array}$ \\
\hline $\begin{array}{l}\text { Current } \\
\text { Ratio }\end{array}$ & 1.49 & 0.86 & 2.25 & 1.59 & 1.93 & 1.36 & 2.32 & 1.55 \\
\hline $\begin{array}{l}\text { Total Debt / } \\
\text { Total Assets }\end{array}$ & $77.16 \%$ & $18.69 \%$ & $71.40 \%$ & $25.59 \%$ & $74.17 \%$ & $22.28 \%$ & $68.29 \%$ & $19.49 \%$ \\
\hline $\begin{array}{l}\text { Short Term } \\
\text { Debt / Total } \\
\text { Debt }\end{array}$ & $51.02 \%$ & $36.11 \%$ & $59.84 \%$ & $27.96 \%$ & $55.61 \%$ & $31.76 \%$ & $48.57 \%$ & $25.22 \%$ \\
\hline $\begin{array}{l}\text { Net Profit / } \\
\text { Shareholder' } \\
\text { s equity }\end{array}$ & $6.72 \%$ & $44.79 \%$ & $17.02 \%$ & $17.28 \%$ & $12.08 \%$ & $33.11 \%$ & $52.27 \%$ & $125.42 \%$ \\
\hline $\begin{array}{l}\text { Net Profit / } \\
\text { Total Assets }\end{array}$ & $4.70 \%$ & $8.03 \%$ & $5.95 \%$ & $7.74 \%$ & $5.35 \%$ & $7.74 \%$ & $11.22 \%$ & $16.13 \%$ \\
\hline $\begin{array}{l}\text { Net Profit / } \\
\text { Net Sales }\end{array}$ & $1.79 \%$ & $2.84 \%$ & $2.36 \%$ & $3.19 \%$ & $2.09 \%$ & $2.98 \%$ & $5.92 \%$ & $12.42 \%$ \\
\hline $\begin{array}{l}\text { EBIT / Net } \\
\text { Sales }\end{array}$ & $3.16 \%$ & $3.93 \%$ & $4.52 \%$ & $6.00 \%$ & $3.87 \%$ & $5.06 \%$ & $6.06 \%$ & $7.85 \%$ \\
\hline $\begin{array}{l}\text { EBITDA / } \\
\text { Net Sales }\end{array}$ & $4.79 \%$ & $5.17 \%$ & $6.52 \%$ & $6.19 \%$ & $5.69 \%$ & $5.67 \%$ & $9.13 \%$ & $8.59 \%$ \\
\hline
\end{tabular}




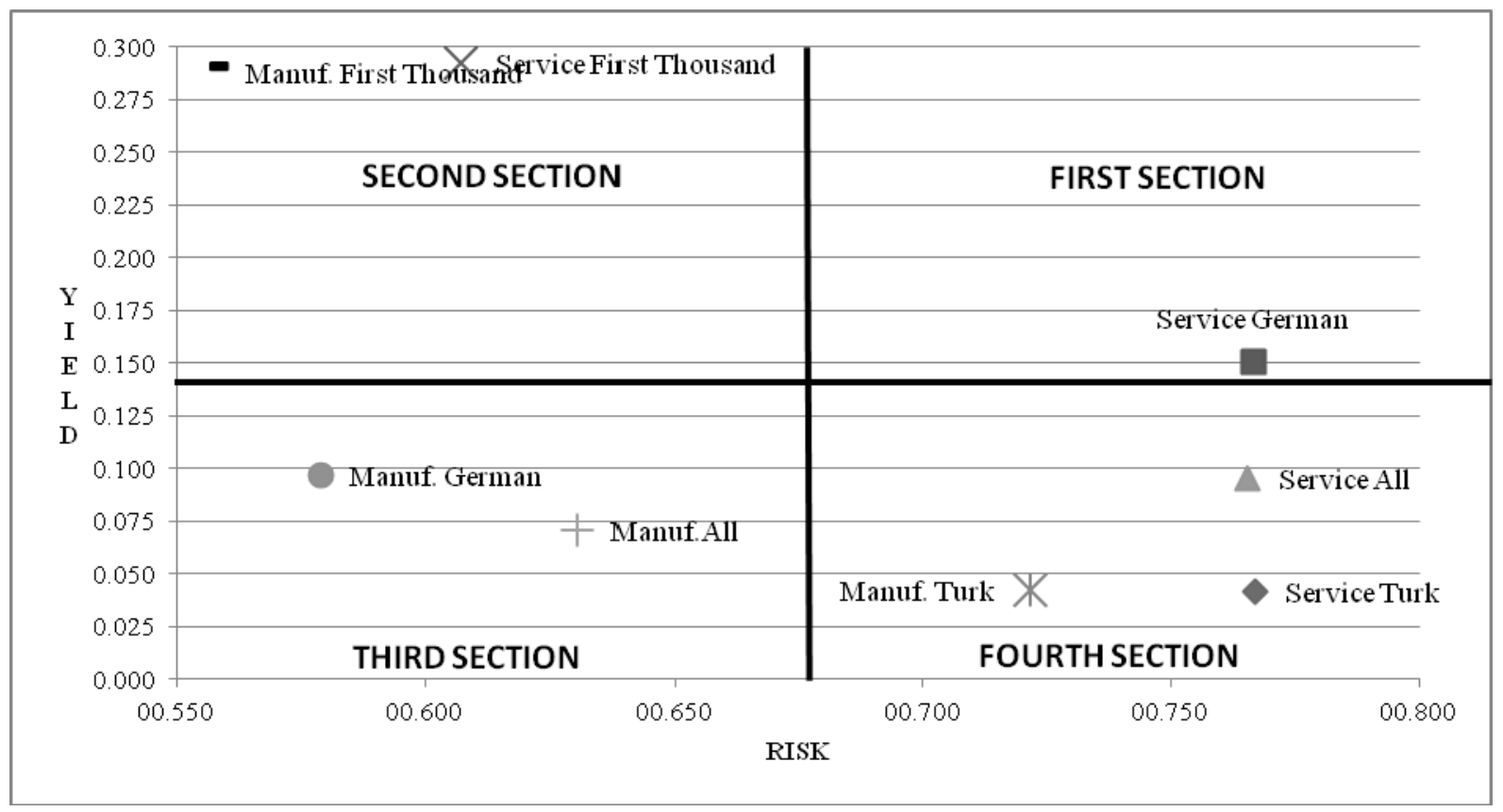

Figure 1. The Relationships between Risk and Yield for Turkish and German Companies 